\title{
Potential Invasiveness for Eucalyptus Species in Florida
}

\author{
Kimberly A. Lorentz and Patrick J. Minogue*
}

\begin{abstract}
To assess the potential invasiveness of common eucalyptus species planted for pulpwood, mulch wood or bioenergy crops, field surveys of eucalyptus seedling recruitment were conducted in north and central Florida locations within seed bearing eucalyptus stands and in the proximate plant communities where seed dispersal may occur. Plant communities included non-grazed pasture, intensively site-prepared forestland, abandoned forest road and upland mixed pine- hardwood forest. No eucalyptus seedlings were found in any of the $3101-\mathrm{m}^{2}$ survey plots across the two locations. Second, seed addition studies were conducted to determine the relative potential for seedling emergence and survival among Eucalyptus amplifolia, E. camaldulensis and E. grandis added into plots at two seed densities, under disturbed and nondisturbed conditions, in the understory of the eucalyptus stands and in each of the aforementioned proximate plant communities. Overall, the probability of emergence of added seed was very low $(\mathrm{P}=0.0$ to 0.0032$)$, and seed density effects were not significant. Emergence was significantly greater in disturbed conditions compared to nondisturbed conditions for seedlings originating from natural seed rain from the eucalyptus canopy in central Florida. The amount of time that seedlings survived was greater for E. camaldulensis compared to the other species but no seedlings survived more than $13 \mathrm{wk}$. These data indicate that under specific favorable conditions, eucalyptus seedlings may establish within or proximate to planted stands, but the overall level of invasiveness demonstrated by E. amplifolia and E. grandis is low for north or central Florida. The demonstrated role of disturbance in facilitating eucalyptus seedling recruitment suggests that a stable perennial plant community (native grasses) should be established instead of bare soil buffer zones to mitigate spread.
\end{abstract}

Nomenclature: Cabbage gum (Eucalyptus amplifolia Naudin); yellow mallee (Eucalyptus incrassata Labill.); river red gum (Eucalyptus camaldulensis Dehnh.); rose gum [Eucalyptus grandis W. Hill ex Maiden].

Key words: Disturbance, establishment, experimental assessment, propagule pressure, survival, weed risk assessment.

Members of the diverse Eucalyptus genus (family Myrtaceae) are native to Australia and over 70 species are naturalized elsewhere (Rejmánek and Richardson 2011). These forestry species are widely planted for pulpwood, mulch wood, energy wood, and windbreaks. After their introduction to many countries, at least seven species have been identified as invasive (Richardson and Rejmánek 2011). Contributing to the extensive propagation of eucalyptus is their perennial growth form, prolific seed production, low incidence of disease, pest resistance, drought tolerance, and their ability to rapidly accumulate biomass and grow in soils of relatively low fertility (Booth 2012). Some eucalypts also have undesirable economic and ecological impacts including increased fire intensity (Pagni

\section{DOI: $10.1614 /$ IPSM-D-14-00030.1}

* Graduate Student and Associate Professor, School of Forest Resources and Conservation, University of Florida, North Florida Research and Education Center, 155 Research Road, Quincy FL 32351. Corresponding author's E-mail: pminogue@ufl.edu
1992), reduction of natural river flows (Le Maitre et al. 2002), and alteration of the native faunal composition and density (Sax 2002). Several eucalyptus species, including $E$. camaldulensis Dehnh., E. grandis W. Hill ex Maiden, and E. amplifolia Naudin, are being planted in the southeastern United States for pulpwood, mulch wood or as bioenergy feedstock (Rockwood 2012). Because of their history of invasiveness elsewhere and their suite of ecologically advantageous traits, potential invasiveness in the southeastern United States is a concern.

Prevention, which can be described as avoidance through appropriate risk assessments and quarantine enforcement (McCormick and Howard 2013), is often considered the most cost-effective approach for dealing with biological invasions (Leung et al. 2002). Two recent studies assessed the invasion risk of eucalyptus in the southeastern United States using observational approaches. Callaham et al. (2013) conducted surveys in the vicinity of 19 eucalyptus stands in Florida and South Carolina to determine the risk of seedling establishment. They observed limited spread of 


\section{Management Implications}

Because of its potential for fast growth and high fiber yields, eucalyptus plantations are being established in the southeastern US Coastal Plain as a source of pulpwood, mulch wood and possibly biofuel. Two quantitative study approaches used within seed bearing Eucalyptus amplifolia stands and their proximate native and modified plant communities in north and central Florida found low invasive potential overall. Surveys at the two locations found no eucalyptus recruitment, suggesting limited success for seedling establishment. The subsequent study evaluated the invasive potential of three commercially important eucalyptus species by adding seed at two densities to disturbed (forest litter or vegetation removed to expose mineral soil) and nondisturbed sites. The combined research findings demonstrated that eucalyptus seedling establishment and survival were generally low at the northern and central Florida locations, although greater numbers of seedlings were observed in disturbed conditions, within the eucalyptus stands and for E. camaldulensis as compared to E. grandis or $E$ amplifolia. Seed addition at 500 or 1000 expected germinants per $\mathrm{m}^{2}$ did result in seedling establishment, but no seedlings survived more than $13 \mathrm{wk}$. Whereas these results do not support previous weed risk assessment conclusions of high invasion risk for $E$. camaldulensis, they suggest that caution is warranted regarding the cultivation of $E$. camaldulensis, especially concerning practices that might increase soil disturbance near eucalyptus stands. The demonstrated role of disturbance in facilitating eucalyptus seedling recruitment suggests that perennial native plant communities should be established instead of bare soil buffer zones. Future research is needed for south Florida where subtropical temperatures favor eucalyptus growth and where commercial plantations are becoming more common.

eucalyptus into unmanaged habitats south of $27^{\circ} \mathrm{N}$, but suggested that further evaluations should be done before Eucalyptus species are adopted for widespread planting. Gordon et al. (2011, 2012) applied the Australian Weed Risk Assessment (WRA), a widely used literature-based tool, to evaluate the risk posed by 38 of the most commercially important Eucalyptus species. The WRA uses 49 "yes" or "no" questions about a species' current weed status in other parts of the world, climate and environmental preferences, and biological attributes, to conclude if a species has high risk, low risk or requires further evaluation (Pheloung et al. 1999). Gordon et al (2012) determined that 15 Eucalyptus species have low risk of invasion in the United States, 14 have high risk and 9 require further information. When the WRA was modified to assess the invasion risk of three species specifically in Florida, Gordon et al (2011) concluded that Eucalyptus grandis and E. camaldulensis posed high invasion risk and that further information was required for E. amplifolia.

While the WRA offers a useful starting point, more quantitative tests are needed to evaluate the many species and taxa of biofuel crops that are being proposed for introduction (Barney and DiTomaso 2008; Chimera et al 2010; Davis et al 2010; Hulme 2011). Invasion risk is shaped not only by species life history traits but also by stochastic processes and local interactions with the biotic and abiotic features of ecosystems in the new range that can greatly affect the population's performance (Hulme 2011; Minton and Mack 2010). These complex processes and relationships are often nonlinear and affected by temporal lag effects and positive feedbacks (Hulme 2011). Therefore, it is difficult to predict invasions based solely on qualitative information using literature-based tools like the WRA.

Experiments are needed to understand invasion risk relative to complex ecological processes and to resolve differing conclusions from observational and literature based work. Experiments to evaluate invasion risk should take into account both the traits of introduced species and the environmental context (Ewel et al 1999; Flory et al. 2012; Parker and Kareiva 1996). Additionally, consideration needs to be given to the effects of propagule pressure and site disturbance on seedling emergence and survival. Disturbance such as vegetation removal is possibly an important driver of invasion (Elton 1958) and has been suggested to be a prerequisite for eucalyptus establishment (Wevill and Read 2010). High propagule pressure has also been observed as one of the mechanisms responsible for tipping the balance to invasion (Lockwood et al. 2005) and it is thought to be an especially important factor for eucalyptus population performance (Gordon 2012; Rejmánek and Richardson 2011). Eucalyptus propagule pressure can potentially be very high considering that seed rain from mature eucalyptus can be up to 4,000 seeds $\mathrm{m}^{-2}$ (Rejmánek and Richardson 2011). Experimental evaluation of invasion risk was needed to understand invasion risk relative to the interacting effects of propagule pressure, species' traits, and environmental conditions; and to resolve unclear conclusions from previous work.

The objective of this study was to evaluate the potential invasiveness of three eucalyptus species being considered for large-scale planting in Florida through two approaches. First, site surveys were conducted to determine the abundance and height distribution of eucalyptus seedling recruitment within seed bearing stands and in the proximate plant communities where nseed dispersal may occur. Plant communities included upland mixed pine-hardwood forest, non-grazed pasture, intensively site-prepared forest land and abandoned forest road. Second, seed addition studies were conducted to determine the relative potential for seedling emergence and survival among E. amplifolia, E. camaldulensis and E. grandis sown at two seed densities under disturbed and nondisturbed conditions in the understory of reproductively mature eucalyptus stands and in each of the aforementioned proximate plant communities.

\section{Materials and Methods}

Study Areas and Surveys. Separate studies were conducted in the proximity of mature E. amplifolia stands at two 
Table 1. Vegetation community characteristics at two Florida study locations.

\begin{tabular}{|c|c|c|c|}
\hline Study location & Vegetation community & Soil series ${ }^{\mathrm{a}}$ & Canopy cover ${ }^{\mathrm{b}}$ \\
\hline & & & $\%$ \\
\hline Gainesville & E. amplifolia seed orchard & Blitchton sand & $74.9 \pm 1.9$ \\
\hline Gainesville & Abandoned forest road & Lochloosa fine sand & $64.0 \pm 4.3$ \\
\hline Gainesville & Upland mixed forest & Blitchton sand & $98.3 \pm 0.2$ \\
\hline Quincy & E. amplifolia progeny test & Dothan-Furquay complex & $90.4 \pm 0.7$ \\
\hline Quincy & Intensively prepared forestland & Dothan Furquay complex & $0.0 \pm 0.0$ \\
\hline Quincy & Non-grazed pasture & Dothan Furquay complex & $0.0 \pm 0.0$ \\
\hline
\end{tabular}

${ }^{a}$ USDA 2012. Web Soil Survey. http://websoilsurvey.nrcs.usda.gov/app/HomePage.htm. Accessed: January 10, 2014.

${ }^{\mathrm{b}}$ Means and standard errors for canopy cover measured over the center of each treatment plot.

locations in Florida during the spring and summer of 2012. Both stands were planted with seedlings or rooted cuttings $1 \mathrm{~m}(3.3 \mathrm{ft})$ apart on rows $3 \mathrm{~m}$ apart, but were thinned to relatively wide spacing between trees providing some direct sunlight in the understory (Table 1), potentially fostering seedling establishment (Booth 2013).

The study in central Florida (Gainesville) was located within and proximate to a E. amplifolia seed orchard on the University of Florida campus $\left(29^{\circ} 37^{\prime} 36^{\prime \prime} \mathrm{N}, 82^{\circ} 21^{\prime} 32^{\prime \prime} \mathrm{W}\right)$ at approximately $23 \mathrm{~m}$ elevation. About half of the trees were planted in 1992 and half in 1995 using seedlings or rooted cuttings placed $1 \mathrm{~m}$ apart on rows $3 \mathrm{~m}$ apart. The stand was 0.4 ha $(1.0 \mathrm{ac})$ with a triangular shape $(104 \mathrm{~m}$ by $80 \mathrm{~m}$ by $76 \mathrm{~m}$ ). At the time of the study the mean stand basal area was $25.7 \mathrm{~m}^{2} \mathrm{ha}^{-} 1$ and the mean height of dominant trees was $34.7 \mathrm{~m}$. There had not been any vegetation management in the $2 \mathrm{yr}$ prior to initiating this study, so the stand contained many other species including silktree (Albizia julibrissin Durazz.), sweetgum (Liquidambar styraciflua L.), water oak (Quercus nigra L.), earleaf greenbriar (Smilax auriculata Walter), and grape (Vitis sp.). The stand is adjacent to an abandoned forest road that supported Carolina dichondra (Dichondra carolinensis Michx.), blackberry (Rubus sp.), water oak seedlings and earleaf greenbriar. The E. amplifolia stand is also adjacent to upland mixed pine-hardwood forest with an overstory canopy comprised of loblolly pine (Pinus taeda L.), live oak (Quercus virginiana Mill.) and American elm (Ulmus americana L.). Virginia creeper (Parthenocissus quinquefolia L.) and eastern poison ivy [Toxicodendron radicans (L.) Kuntze] were common in the understory of the upland mixed forest. The Gainesville location has a temperate climate with highest temperatures in July (mean $27 \mathrm{C}$ or $80.6 \mathrm{~F}$ ), lowest temperatures in January (mean $13 \mathrm{C}$ ), a mean extreme minimum temperature of -6.7 to $-3.9 \mathrm{C}$, and $125 \mathrm{~cm}$ (49 in) mean annual precipitation (NOAA 2002).

The study in north Florida (Quincy) was located within and proximate to a $150 \mathrm{~m}$ by $60 \mathrm{~m} 0.9$ ha E. amplifolia progeny test planted with container seedling stock in 1999 at the North Florida Research and Education Center, south of Quincy $\left(30^{\circ} 32^{\prime} 32^{\prime \prime} \mathrm{N}, 84^{\circ} 35^{\prime} 25^{\prime \prime} \mathrm{W}\right)$ at approximately $73 \mathrm{~m}$ elevation. At the time of the study the mean stand basal area was $24.1 \mathrm{~m}^{2} \mathrm{ha}^{-1}$ and the mean height of dominant trees was $23.8 \mathrm{~m}$. The stand also contained Chinese privet (Ligustrum sinense Lour.), common persimmon (Diospyros virginiana L.), eastern cottonwood (Populus deltoides W. Bartram ex Marshall) and blackberry. This stand is adjacent to non-grazed pasture comprised of vaseygrass (Paspalum urvillei Steud.) and field paspalum (Paspalum laeve Michx.). The stand is also adjacent to intensively site prepared forestland that previously supported a 13-yr-old eastern cottonwood clone test, harvested in January 2012, and was prepared for planting eucalyptus in March 2012 by the rake/pile/burn/disk method (Lowery and Gjerstad 1991). The plant community on the intensively prepared forestland contained a diverse array of species including dogfennel [Eupatorium capillifolium (Lam.) Small], redstar (Ipomoea coccinea L.), tievine (Ipomoea cordatotriloba Dennst.), common yellow oxalis (Oxalis stricta L.), purple passionflower (Passiflora incarnata L.), pink purslane (Portulaca pilosa L.) and sicklepod (Senna obtusifolia L.). The Quincy location has highest temperatures in July (mean $27 \mathrm{C}$ ), lowest temperatures in January (mean $10 \mathrm{C}$ ), a mean extreme minimum temperature of -9.4 to $-6.7 \mathrm{C}$, and $143 \mathrm{~cm}$ mean annual precipitation (NOAA 2002).

In May 2012, line transect sampling was used to identify natural recruitment of $E$. amplifolia seedlings from the mature eucalyptus trees. At each study location, $1 \mathrm{~m}^{2}$ plots (72 Gainesville, 238 Quincy) were evaluated using a sampling frame placed every $10 \mathrm{~m}$ on line transects established $20 \mathrm{~m}$ apart across the narrow dimension of the stand and $60 \mathrm{~m}$ into the proximate plant communities. Eucalyptus seeds are typically dispersed by wind within an estimated radius equal to twice the canopy or tree height (Cremer 1966, 1977), and $60 \mathrm{~m}$ is approximately twice the canopy height of these stands. At Gainesville there were 10 transects with 25 sample points within the eucalyptus stand, 22 within the abandoned forest road and 25 sample 
points in upland mixed pine-hardwood forest. At Quincy there were 14 transects with 56 sample points within the eucalyptus stand, 134 sample points within non-grazed pasture and 48 sample points within intensively siteprepared forestland.

Germination Testing. Seeds were collected from wild trees in Australia between 1999 and 2008 and stored frozen by the University of Florida Seed Foundation prior to our use. Germination capacity of Eucalyptus species is highly variable, ranging from $11 \%$ to $98 \%$ (USDA 2008). Prior to initiating the seed addition experiment, the expected germination rates of E. amplifolia, E. camaldulensis and E. grandis seed stocks were determined in order to calculate the amount of seed needed to give equal numbers expected seedling establishment in seed addition experiment plots. The germination rate for each species was determined by measuring the mean number of germinating seeds per $\mathrm{g}$. The use of weight-specific germination rates was preferable because eucalyptus seeds are small ( 1 to $3 \mathrm{~mm}(0.04-0.12$ in) long and weigh less than $0.5 \mathrm{mg}$ to $2.0 \mathrm{mg}(1.8 \times$ $10^{-5}$ oz to $7.1 \times 10^{-5} \mathrm{oz}$ ) [Rejmánek and Richardson 2011]) and are intermixed with inert chaff from their woody seed capsules, making it difficult to count individual seeds accurately. Germination was evaluated in a seed incubator under conditions that corresponded to mean minimum $(20.1 \mathrm{C})$ and maximum $(32.5 \mathrm{C})$ temperature (NOAA 2002) and $14 \mathrm{~h}$ photoperiod for June in northcentral Florida (NMOC 2012). Light was provided with the higher temperature for $14 \mathrm{~h}$, followed by the lower temperature without light for $10 \mathrm{~h}$. While some alpine Eucalyptus species require cold-moist stratification (Boland 1986), the species used in this study are not known to require any dormancy breaking procedures. Eight $0.05 \mathrm{~g}$ $\left(1.8 \times 10^{-6} \mathrm{oz}\right)$ samples of each seedlot were tested for each species. All materials that were exposed to seeds during preparation of the samples were autoclaved to reduce the likelihood of microbial growth. Samples were placed in $9 \mathrm{~cm}$ glass Petri dishes containing two thicknesses of filter paper as a substrate. Three $\mathrm{ml}(0.1 \mathrm{oz})$ of sterile distilled water was applied to the filter paper using a glass pipette. Seeds were dispersed evenly over the filter paper, and the Petri dishes were sealed with paraffin film to prevent samples from desiccating. A germination count was made after $5 \mathrm{~d}$ and every $2 \mathrm{~d}$ thereafter. During each count, normal and abnormal germinated seeds were counted separately and removed from the dish. A normal eucalyptus seedling had a healthy radicle, hypocotyl and cotyledons. The recommended test duration for E. grandis is $14 \mathrm{~d}$, and while there were no specific recommendations for the test duration for E. amplifolia and E. camaldulensis, 10 to $21 \mathrm{~d}$ is generally suitable for most species (Boland 1986). The final count was made at $14 \mathrm{~d}$ and the total number of normal germinated seeds in each sample was used to calculate the mean number of germinating seeds per g. The germination rates for E. grandis, E. amplifolia, and $E$. camaldulensis were 655 seeds $\mathrm{g}^{-1}$ (SD 174), 92 seeds $\mathrm{g}^{-1}$ (SD 29), and 388 seeds $\mathrm{g}^{-1}$ (SD 113), respectively, with differences among species means using Fisher's Protected LSD test.

Experimental Design of Seed Addition Studies. The potential for eucalyptus seedling establishment and survival in common native or modified vegetation communities was evaluated through a seed addition approach similar to da Silva et al. (2011). Sampling plots were established within the understory of the E. amplifolia stand and in two proximate communities at both study locations, resulting in 63 plots at each location. At the Gainesville location, proximate communities included an upland mixed pinehardwood forest and an abandoned forest road. At the Quincy location, proximate communities included a nongrazed pasture and an intensively prepared site for eucalyptus planting, as described above. In each vegetation community, seeds of E. amplifolia, E. camaldulensis and E. grandis were placed on separate nested paired plots to examine the effects of disturbance and seeding density for each species. Adjacent $0.75 \mathrm{~m}^{2}$-paired plots were randomly left nondisturbed or were disturbed through removal of the vegetation layer and soil scarification with a rake. In the center of each of the paired plots, two nested $0.25 \mathrm{~m}$ by $0.25 \mathrm{~m}$ paired subplots were randomly assigned to addition of amounts of seed expected to result in either 500 or 1,000 germinated seedlings $\mathrm{m}^{-2}$ (equivalent to 31 or 62 expected seedlings per subplot). These levels were chosen to reflect the hypothesized intermediate and maximum levels that occur naturally based on estimates of actual seed rain in the literature (Virtue and Melland 2003). The $0.625 \mathrm{~m}^{2}$ nonseeded areas outside of the smaller nested paired seeded subplots within the disturbed or nondisturbed treatments were used to observe eucalyptus seedling establishment from mature trees. Randomly distributed paired plots were replicated eight times in each vegetation community type for E. amplifolia and E. grandis, and only five times for $E$. camaldulensis, because of a shortage of seed. Seeds were added on June 7, 2012 in Quincy and on June 8, 2012 in Gainesville, following $2.0 \mathrm{~cm}$ and $13.1 \mathrm{~cm}$ of rain (tropical storm event) in the previous $24 \mathrm{~h}$ at each location, respectively (IFAS 2012).

Seedlings were counted at 2, 4, 6, 8, 11, 14, 17, 21, and $25 \mathrm{wk}$ after seeds were added into plots to determine emergence and survival of eucalyptus seedlings. Newly emerged seedlings at each counting date were marked with uniquely colored toothpicks to distinguish them from new seedlings in subsequent counts. Surviving seedlings of each emergence date group were counted at each census so that the approximate length of time that seedlings survived could be determined. 
Statistical Analyses. Germination Rates and Field Emergence. Seed incubator mean germination rates for the three Eucalyptus species were compared using Fisher's Protected LSD test. The low level of emergence observed in field studies allowed for three statistical models that were of interest.

1. The cumulative eucalyptus seedling emergence count was compared for seeded and nonseeded areas of plots located within the eucalyptus stands at the two study locations in order to determine if there was a difference in emergence because of adding seed compared to the base levels of seed rain. Emergence was analyzed using a generalized linear model with a Poisson distribution. The natural log of subplot area was used as an offset (McCullagh and Nelder 1989) to account for different seeded and nonseeded subplot size.

2. In order to determine if treatment effects were significant, cumulative eucalyptus seedling emergence counts, expressed as the proportion of seedlings that emerged relative to the expected 93 total seedlings in paired subplots, were used as a response variable. Emergence data from both locations were analyzed together in a generalized linear model with a binomial distribution and a logit link function using PROC GLIMMIX (SAS v. 9.3, SAS Institute, Cary, NC). Community, species, disturbance, disturbance by species, and species by community were considered fixed effects. Emergence data were pooled across high and low density seeded subplots because seedling counts were too low to evaluate the effect of seeding density in each subplot, and seeding density effects were not significant. The random effect of plot within each community was removed from the model because it was a source of nonconvergence. Insignificant interactions were also removed.

3. The cumulative eucalyptus seedling emergence counts, summed across nonseeded areas of the 21 disturbance treatment plots (total $13.1 \mathrm{~m}^{2}$ ) within the two eucalyptus stands, served as an additional response variable. This variable reflected seedling emergence caused by natural recruitment. A generalized linear model (PROC GLIMMIX) was used to analyze the fixed effect of disturbance. Counts were summed across plots within a community because variation across plots could not be estimated because of the absence of observed emergence is some plots.

Survival. The duration of survival for each of the eucalyptus seedlings observed was determined based on when each seedling was first observed and when it was last observed. The middle value of this range was assigned to each seedling to approximate survival time. Pearson's chisquared tests (PROC FFREQ) (SAS v. 9.3, SAS Institute, Cary, NC) were used to analyze the significance of species, disturbance and vegetation community for ranges of survival time $(<1 \mathrm{mo}, 1$ to $2 \mathrm{mo},>2 \mathrm{mo})$. Survival data were pooled for the Gainesville and Quincy locations because survival time did not differ by location. Analyses of survival time for the three species were performed using the number of observed seedlings in both seed addition subplots and in the surrounding whole plots, to account for the possibility of movement of the added seed. The significance level for all tests was $\alpha=0.05$.

\section{Results and Discussion}

Study Area Surveys. The $1-\mathrm{m}^{2}$ survey plots in the eucalyptus stands and proximate plant communities included various types of ground cover: grasses, vines, forbs, shrubs, trees, bare mineral soil and leaf litter. No eucalyptus seedlings were found in any of the 72 plots at the Gainesville study location or in the 238 plots at the Quincy location. Flowering in E. amplifolia occurs relatively late compared to other species, typically not flowering abundantly until approximately age 8 yr (personal communication, Donald Rockwood, Professor Emeritus, University of Florida). Eucalyptus was planted at the Gainesville location in 1992 and 1995, so trees had been producing seed for 12 to $9 \mathrm{yr}$ at the time of the study. The Quincy site was planted in 1999 and trees had likely been producing seed for $5 \mathrm{yr}$ prior to the survey. The lack of natural eucalyptus recruitment observed in these surveys is consistent with results of a similar study that found natural recruitment of eucalyptus seedlings adjacent to only 4 of 16 surveyed eucalyptus stands in Florida (Callaham et al. 2013). Similar surveys in Brazil found recruitment within eucalyptus stands, but not in adjacent pine communities (Emer and Fonseca 2010).

Main Effect of Seeding. In the Gainesville study, seedling emergence in seed addition subplots was not significantly different $(P=0.947)$ than the level of emergence resulting from natural seed rain. In contrast, at Quincy emergence was significantly greater $(P=0.017)$ in seeded areas compared to the surrounding nonseeded areas, that were used as an experimental control to quantify seed rain. The older stand in Gainesville may have produced more seed, diminishing the effect of seed addition. The disparity in the significance of seeding at the two sites may also be related to heavy rainfall in Gainesville, which could have spread seed from the subplots into the surrounding nonseeded area. A tropical storm event in Gainesville caused $13.3 \mathrm{~cm}$ of rainfall in the week following seeding treatments, whereas only $1.8 \mathrm{~cm}$ of rainfall occurred in Quincy as the result of this system. Although the effect of seed removal by insects was not examined in this study, previous studies suggest that it should be considered as a possible factor contributing to differences in seeding emergence at 
Table 2. Probability of emergence and predicted seedlings per hectare for added Eucalyptus seed of three species in various community types at two study locations in Florida, as predicted by a generalized linear model.

\begin{tabular}{|c|c|c|c|c|}
\hline Location & Vegetation community & Eucalyptus species & $\begin{array}{c}\text { Probability of seedling } \\
\text { emergence }\end{array}$ & Predicted seedlings ha ${ }^{-1}$ \\
\hline \multirow[t]{9}{*}{ Gainesville } & \multirow[t]{3}{*}{ Eucalyptus stand } & E. amplifolia & $3.02 \times 10^{-11}$ & 0.00 \\
\hline & & E. camaldulensis & $3.24 \times 10^{-03}$ & $24,068.40$ \\
\hline & & E. grandis & $1.27 \times 10^{-03}$ & $9,426.48$ \\
\hline & \multirow[t]{3}{*}{ Forest road } & E. amplifolia & $4.46 \times 10^{-06}$ & 33.20 \\
\hline & & E. camaldulensis & $1.29 \times 10^{-03}$ & $9,597.60$ \\
\hline & & E. grandis & $6.34 \times 10^{-04}$ & $4,716.96$ \\
\hline & \multirow[t]{3}{*}{ Upland mixed forest } & E. amplifolia & $3.02 \times 10^{-11}$ & 0.00 \\
\hline & & E. camaldulensis & $2.59 \times 10^{-09}$ & 0.02 \\
\hline & & E. grandis & $3.66 \times 10^{-09}$ & 0.03 \\
\hline \multirow[t]{9}{*}{ Quincy } & \multirow[t]{3}{*}{ Eucalyptus stand } & E. amplifolia & $4.46 \times 10^{-06}$ & 33.20 \\
\hline & & E. camaldulensis & $1.94 \times 10^{-03}$ & $14,411.28$ \\
\hline & & E. grandis & $3.66 \times 10^{-09}$ & 0.03 \\
\hline & \multirow[t]{3}{*}{ Non-grazed pasture } & E. amplifolia & $3.02 \times 10^{-11}$ & 0.00 \\
\hline & & E. camaldulensis & $2.59 \times 10^{-09}$ & 0.02 \\
\hline & & E. grandis & $3.66 \times 10^{-09}$ & 0.03 \\
\hline & \multirow[t]{3}{*}{ Intensively prepared forestland } & E. amplifolia & $3.02 \times 10^{-11}$ & 0.00 \\
\hline & & E. camaldulensis & $2.59 \times 10^{-09}$ & 0.02 \\
\hline & & E. grandis & $3.66 \times 10^{-09}$ & 0.03 \\
\hline
\end{tabular}

the two locations. Wellington and Noble (1985) found that in stands of Eucalyptus incrassata Labill. in Australia, which had natural seed rain up to $10^{-6}$ seed $\mathrm{ha}^{-1} \mathrm{yr}^{-1}, 65$ to $100 \%$ of seeds were harvested rapidly by ants, although seed harvesting activity was spatially and temporally variable.

Treatment Effects on Emergence of Added Seed. Differences in the probability of emergence for disturbance treatment, Eucalyptus species, vegetation community type, and interactions between and among these factors were not significant. The predicted probabilities of eucalyptus seedling emergence in seed addition subplots varied by up to eight orders of magnitude for different treatment combinations, but were very low overall $(\mathrm{P}=0.0$ to 0.0032) (Table 2). These predicted levels of seedling emergence became meaningful when propagule pressure was considered on a per hectare basis (e.g., 500 germinated seeds $\mathrm{m}^{-2}$ is equivalent to $5 \times 10^{6}$ germinants ha ${ }^{-1}$ ). Predicted emergence was generally higher within disturbed (7.61 seedlings $\left.\mathrm{ha}^{-1}\right)$ than in nondisturbed areas (0.06 seedlings $\left.\mathrm{ha}^{-1}\right)$. The highest level of emergence for the three tested Eucalyptus species was predicted for $E$. camaldulensis (17 seedlings ha ${ }^{-1}$ ). The Gainesville eucalyptus stand had the highest predicted emergence (37 seedlings $\mathrm{ha}^{-1}$ ) among the various vegetation communities studied. Correspondingly, the vegetation community by species combination that yielded the highest predicted seedling emergence was E. camaldulensis in the Gainesville eucalyptus stand $\left(24,068\right.$ seedlings $\left.\mathrm{ha}^{-1}\right)$ (Table 2). Da Silva et al. (2011) reported similar low levels of eucalyptus emergence in seed addition studies in Brazilian plant communities. When approximately 10,000 total seeds were added across forty $1 \mathrm{~m}^{2}$ plots, only 111 total seedlings were observed at five periodic censuses. In their study, new seedlings were not distinguished from survivors in previous counts, so assuming some level of seedling mortality during the 1-yr census, the number of emerged eucalyptus seedlings would be higher than the total number at periodic assessments. They observed the greatest mean number of eucalyptus seedlings (37) in disturbed plots within the eucalyptus stand at $15 \mathrm{~d}$ from sowing. At $180 \mathrm{~d}$ from sowing only one seedling survived across all of their seed addition treatments and no seedlings were observed at 270 or $360 \mathrm{~d}$ from sowing, supporting their conclusion of low invasive potential.

Disturbance and Emergence from Natural Seed Rain. The effect of disturbance on emergence of eucalyptus seedlings in nonseeded areas, which are assumed to originate from natural seed rain, was significant $(\mathrm{P}=$ 0.0005) in the Gainesville eucalyptus stand. The generalized linear model predicted greater emergence for the disturbed condition $(18,004,95 \%$ confidence interval 9,403 to 35,846 seedlings $\mathrm{ha}^{-1}$ ) compared to the nondisturbed condition $(3,317,95 \%$ confidence interval 1,232 to 8,931 seedlings $\mathrm{ha}^{-1}$ ). In Quincy, the effect of disturbance was not significant $(P=0.097)$. It is likely that 


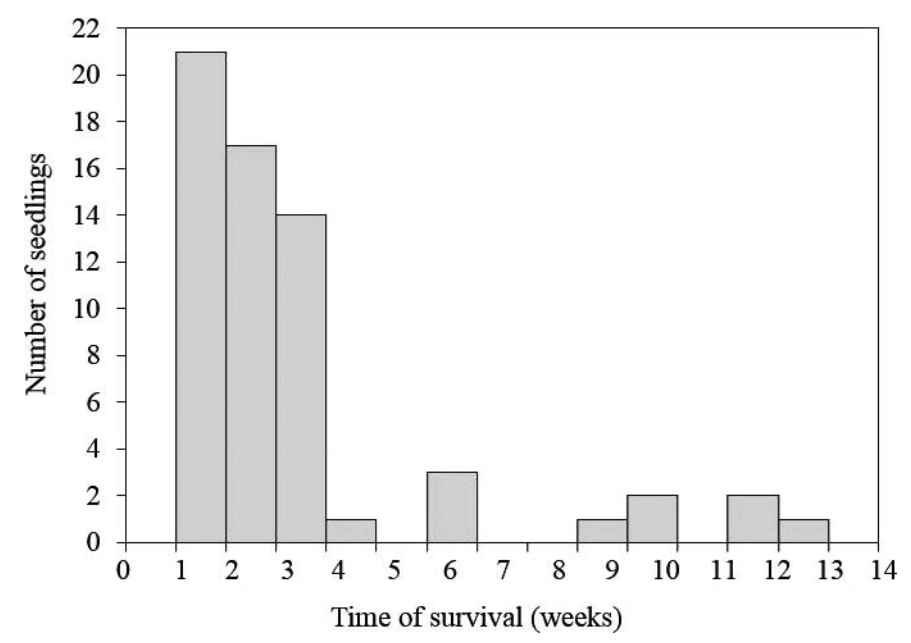

Figure 1. Duration of Eucalyptus seedling survival across three Eucalyptus species (E. amplifolia, E. camaldulensis, E. grandis) and two study locations in Florida. No seedlings survived more than 13 wk.

the sample size of only three seedlings in nonseeded areas in Quincy was inadequate to detect differences in emergence because of disturbance. This trend of greater emergence in disturbed areas was expected considering that disturbance improved germination of Eucalyptus seedlings in other studies (da Silva et al. 2011). This result also supports the hypothesis of Wevill and Read (2010) that rare disturbances such as fire or flooding which suppress competition are necessary for eucalyptus to establish because eucalyptus seedlings are sustained by cotyledon photosynthesis and must establish roots quickly in a suitable environment (Rejmánek and Richardson 2011).

Seedling Survival. Of the 62 seedlings that emerged, 54 seedlings (86\%) survived less than $1 \mathrm{mo}$, and none survived for more than 13 wk (Figure 1). Pearson's chi-squared tests found that vegetation community and disturbance did not significantly affect the amount of time that seedlings survived. Species emerged as a significant factor affecting the amount of time that seedlings survived $\left(\chi^{2}=9.72,4 \mathrm{df}\right.$, $n=62, \mathrm{P}=0.045)$. While all three species had a similar number of seedlings that survived for up to 2 mo, only seedlings in plots seeded with E. camaldulensis survived for more than 2 mo (Figure 2). Similar to these results, Emer and Fonseca (2010) also found that eucalyptus seedlings that were transplanted into various native and modified communities were short lived, surviving only 2.7 to $9.3 \mathrm{mo}$. The significantly greater time of survival that was detected for E. camaldulensis, in combination with the highest predicted emergence observed in the seed addition studies, may indicate that $E$. camaldulensis does have a relatively greater ability to establish than the other species tested. These results may support previous research that suggested E. camaldulensis has high potential for invasiveness.

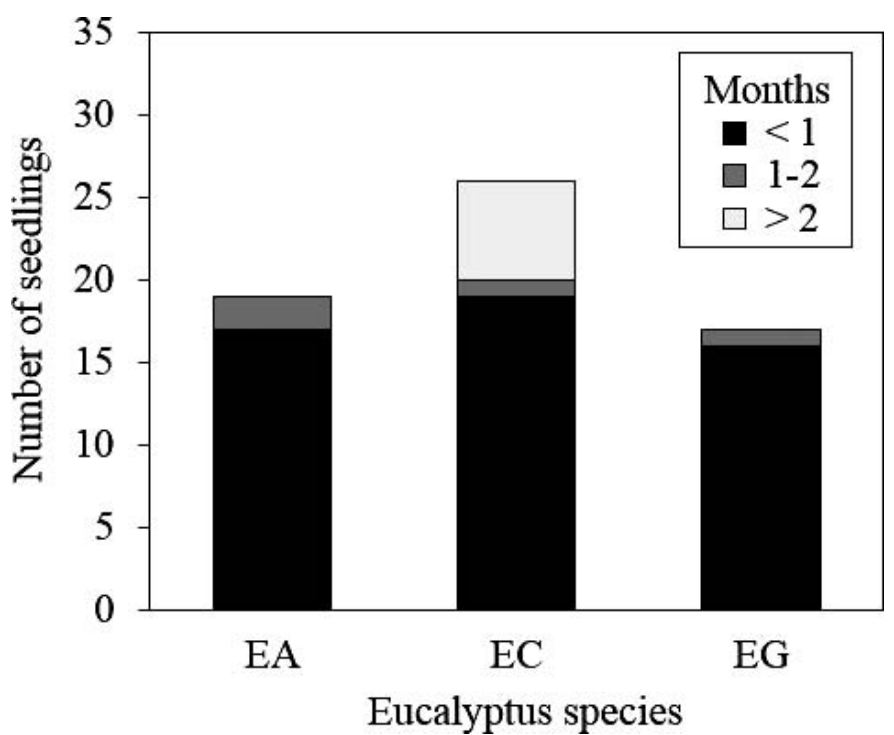

Figure 2. Duration of seedling survival for E. amplifolia (EA), E. camaldulensis (EC) and E. grandis (EG) seedlings across two study locations in Florida. No seedlings survived more than 13 wk.

Gordon et al. (2012) determined that E. camaldulensis has a Weed Risk Assessment (WRA) score of 18, representing a high invasion risk level and tying with Tasmanian blue gum (Eucalyptus globulus Labill.) as the eucalyptus species with the highest score out of the 38 species evaluated. Additionally, Rejmánek and Richardson (2011) reported that E. camaldulensis is the most widespread eucalyptus species and has naturalized in 16 regions globally. However, the failure of E. camaldulensis seedlings to survive beyond $13 \mathrm{wk}$ also provides support contrary to the high invasion risk level predicated by the Weed Risk Assessment (Gordon 2012). Our mixed findings regarding E. camaldulensis invasiveness suggest that it may be appropriate to recommend that $E$. camaldulensis growers implement invasion risk management practices as a precautionary measure.

\section{Acknowledgments}

The authors thank Dr. Donald Rockwood, Professor Emeritus, University of Florida and the Florida Seed Foundation for their contribution of seed materials for this study. We also thank Dr. Dwight Lauer, Silvics Analytic, for his assistance with statistical analyses.

\section{Literature Cited}

Barney JN, DiTomaso JM (2008) Nonnative species and bioenergy: Are we cultivating the next invader? Bioscience 58:1-7

Boland DJ (1986) Testing and storage of Eucalyptus and Acacia seed. Pages 75-94 in Proceedings of a Workshop on Seed Handling and Eucalypt Taxonomy. Harare, Zimbabwe: Forestry Commission of 
Zimbabwe and the International Development Research Centre (Canada)

Booth TH (2013) Eucalypts and their potential for invasiveness particularly in frost-prone regions. Int J For Res. DOI: 10.1155/ 2012/837165

Callaham MA Jr, Stanturf JA, Hammond WJ, Rockwood DL, Wenk ES, O’Brien JJ (2013) Survey to evaluate escape of Eucalyptus spp. seedlings from plantations in Southeastern USA. Int J For Res. DOI: $10.1155 / 2013 / 946374$

Chimera CG, Buddenhagen CE, Clifford PM (2010) Biofuels: the risks and the dangers of introducing invasive species. Biofuels 1:785-596

Cremer KW (1977) Distance of seed dispersal in eucalypts estimated from seed weights. Aust For Restor 7:225-228

Cremer KW (1966) Dissemination of seed from Eucalyptus regnans. Australian Forestry 30:33-37

da Silva PHM, Poggiani F, Sebbenn AM, Mori ES (2011) Can Eucalyptus invade native forest fragments close to commercial stands? Forest Ecol Manag 26:2075-2080

Davis AS, Cousens RD, Hill J, Mack RN, Simberloff D, Raghu S (2010) Screening bioenergy feedstock crops to mitigate invasion risk. Frontiers Ecol Environ 8:533-539

Elton CS (1958) The Ecology of Invasions by Animals and Plants. London: Methuen

Emer C, Fonseca CR (2010) Araucaria forest conservation: mechanisms providing resistance to invasion by exotic timber trees. Biol Invasion 13:189-202

Ewel JJ, O’Dowd DJ, Bergelson J, Daehler CC, D’Antonio CM, Gómez LD, Gordon DR, Hobbs RJ, Holt A, Hopper KR, Hughes CE, LaHart M, Leakey RRB, Lee WG, Loope LL, Lorence DH, Louda SM, Lugo AE, McEvoy PB, Richardson DM, Vitousek PM (1999) Deliberate introductions of species: research needs. Bioscience 49: 619-30

Flory SL, Lorentz KA, Gordon DR, Sollenberger LE (2012) Experimental approaches for evaluating the invasion risk of biofuel crops. Environ Res Lett. DOI: 10.1088/1748-9326/7/4/045904

Gordon DR, Flory SL, Cooper AL, Morris SK (2012) Assessing the invasion risk of Eucalyptus in the United States using the Australian weed risk assessment. Int J For Res. DOI: 10.1155/2012/203768

Gordon DR, Tancig KJ, Onderdonk DA, Gantz CA (2011) Assessing the invasive potential of biofuel species proposed for Florida and the United States using the Australian weed risk assessment. Biomass Bioenerg 35:74-79

Hulme PE (2011) Weed risk assessment: a way forward or a waste of time? J Appl Ecol. 49:10-29

[IFAS] Institute of Food and Agricultural Sciences (2012) Florida Automated Weather Network. http://fawn.ifas.ufl.edu/. Accessed: January 10, 2013

Le Maitre DC, van Wilgen BW, Gelderblom CM, Bailey C, Chapman RA, Nel JA (2002) Invasive alien trees and water resources in South Africa: case studies of the costs and benefits of management. For Ecol Manag 160:143-159

Leung B, Lodge DM, Finnoff D, Shogren JF, Lewis MA, Lamberti G (2002) An ounce of prevention or a pound of cure: bioeconomic risk analysis of invasive species. Proc R Soc Lond B 269:2407-2413

Lockwood JL, Cassey P, Blackburn T (2005) The role of propagule pressure in explaining species invasions. Trends Ecol Evol 20:223-8

Lowery RF, Gjerstad DH (1991) Chemical and mechanical site preparation. Pages 251-261 in Duryea ML, Dougherty PM, eds. Forest Regeneration Manual. Dordrecht, The Netherlands: Kluwer
McCormick N, Howard G (2013) Beating back biofuel crop invasions: Guidelines on managing the invasion risk of biofuel developments. Renew Energ 49:263-266

McCullagh P, Nelder JA (1989) Generalized Linear Models. Monographs on statistics and applied probability 37 . Second edition. Boca Raton, FL: Chapman \& Hall/CRC. 511 pp

Minton MS, Mack RN (2010) Naturalization of plant populations: the role of cultivation and population size and density. Oecologia 164: 399-409

[NMOC] Naval Meteorology andOceanography Command (2012) Complete sun and moon data for one day: U.S. Cities and Towns. Stennis Space Center, MS. http://aa.usno.navy.mil/data/docs/RS_ OneDay.php. Accessed: May 15, 2012

[NOAA] National Oceanic and Atmospheric Administration (2002) Monthly station normals of temperature, precipitation, and heating and cooling degree days 1971-2000. in Climatography of the United States, No. 81.08-Florida. Asheville, NC: NOAA National Climatic Data Center and National Environmental Satellite, Data, and Information Service. http://cdo.ncdc.noaa.gov/climatenormals/clim81/ FLnorm.pdf. Accessed: June 10, 2011

Pagni PJ (1993) Causes of the 20 October 1991 Oakland Hills conflagration. Fire Safety J 2:331-339

Parker IM, Kareiva P (1996) Assessing the risks of invasion for genetically engineered plants: acceptable evidence and reasonable doubt. Biol Conserv 78:196-208

Pheloung PC, Williams PA, Halloy SR (1999) A weed risk assessment model for use as a biosecurity tool evaluating plant introductions. J Environ Manage 57:239-251

Rejmánek M, Richardson DM (2011) Eucalypts. in Simberloff D, Rejmánek M, eds. Encyclopedia of Biological Invasions. Berkeley, CA: University of California Press, 203-209

Richardson DM, Rejmánek M (2011) Trees and shrubs as invasive alien species - a global review. Divers Distrib 17:788-809

Rockwood DL (2012) History and Status of Eucalyptus Improvement in Florida. Int J For Res. DOI: 10.1155/2012/607879

Sax DF (2002) Equal diversity in disparate species assemblages: a comparison of native and exotic woodlands in California. Global Ecol Biogeog 11:49-57

[USDA] United States Department of Agriculture, Agricultural Research Service (2012) Plant Hardiness Zone Map. http:// planthardiness.ars.usda.gov/PHZMWeb/. Accessed: January 10, 2013

[USDA] United States Department of Agriculture, Forest Service (2008) Agriculture Handbook 727. The Woody Plant Seed Manual. Pp. 504-512

Virtue JG, Melland RL (2003) The environmental weed risk of revegetation and forestry plants. Adelaide, South Australia: Department of Water, Land and Biodiversity Conservation Report DWLBS2003/02. $184 \mathrm{p}$

Wellington AB, Noble IR (1985) Seed dynamics and factors limiting recruitment of mMallee Eucalyptus incrassata in semi-arid, southeastern Australia. J Ecol 73:657-666

Wevill T, Read J (2010) Fine-scale patterns in the distribution of semiarid tree species at Wyperfeld National Park, southeastern Australia the potential roles of resource gradients vs. disturbance. J Arid Environ 74:482-490

Received April 23, 2014, and approved September 2, 2014. 